\title{
Biofilter implementation with Minerals (Zeolite - Activated Carbon) for wastewater treatment in the Orquídeas Stabilization Lagoon, Cerro Colorado - Guayaquil
}

\author{
Ing Cortez-Quiñonez Andres ', Ing . Muñoz-Naranjo Diego M.Sc. ${ }^{2}$, Ing. Guevara-Sáenz de Viteri Jessica M.Sc ${ }^{3}$ \\ 1.Universidad Agraria del Ecuador, Faculty of Agrarian Sciences; herramientas93@hotmail.com \\ 2.Universidad Agraria del Ecuador, Faculty of Agrarian Sciences; dmunoz@uagraria.edu.ec \\ 3.Universidad de Guayaquil, Faculty of Philosophy, Letters and Educational Sciences, Member of \\ OIICE; jessica.guevaras@ug.edu.ec Orcid 0000-0003-1148-0014
}

\begin{abstract}
Resumen- Este documento se centra en la implementación de biofiltros a base de minerales (Zeolita y Carbón Activado) en escala de laboratorio, para la depuración de aguas residuales provenientes de la Laguna de Estabilización Orquídeas, con la finalidad de reducir los parámetros contaminantes que posee y permitir la reutilización de este recurso.

De acuerdo con el estudio realizado, este documento tuvo como misión evaluar y analizar componentes tales como zeolita y carbón activado, dos materiales que además de ser minerales sirven como un mecanismo de filtración, absorción y eliminación de contaminantes.

$Y$ acorde con sus resultados en tratamiento de cada uno, se identificó y estableció el biofiltro eficiente en depuración.
\end{abstract}

Palabras clave: carbón activado, biofiltros, laguna de estabilización, aguas residuales, zeolita.

Abstract - This document focuses on the implementation of biofilters based on minerals (Zeolite and Activated Carbon) on a laboratory scale, for the purification of wastewater from the Orquideas Stabilization Lagoon, in order to reduce the contaminating parameters, it has and allow reuse of this resource.

According to the study carried out, this document had the mission of evaluating and analyzing components such as zeolite and activated carbon, two materials that besides being minerals serve as a mechanism for filtration, absorption and elimination of contaminants. And according to their results in treatment of each one, the biofilter was identified and established in purification efficient.

Keywords - Activated Carbon, Biofilters, Stabilization Lagoon, Wastewater, Zeolite.

\section{INTRODUCTION}

One of the main problems on the conservation and management of water resources is contamination by spills or direct storage of wastewater to other tributaries such as rivers, lakes, ravines, etc. The generators of these actions are the urban, industrial and agricultural sector [2].

$90 \%$ of wastewater in developing countries is discharged without treatment, in Latin America only 14\% of wastewater is treated and of that $14 \%$, only $6 \%$ receives adequate treatment [10].

In Ecuador, the accumulation and management of wastewater only covers between $41 \%$ and $58 \%$ of provinces such as Pichincha, Carchi, Tungurahua, Imbabura and El Oro with the highest coverage of sanitary sewerage in the country [16]. However, at the national level there is no complete and standard coverage to treat the wastewater generated by each province [6].

The country shows problems with the total coverage of wastewater, which is where the largest amount of wastewater generated by human activity is located, obtaining for 2017 a coverage percentage of $63.1 \%$, giving the rest of its wastewater no treated, to be stored in tanks such as lagoons or swimming pools, infiltrate the dwelling into the ground through septic tanks, latrines, etc. or simply discharged into tributaries such as rivers [16].

Digital Object Identifier (DOI):

http://dx.doi.org/10.18687/LACCEI2020.1.1.130

ISBN: 978-958-52071-4-1 ISSN: 2414-6390

$\mathbf{1 8}^{\text {th }}$ LACCEI International Multi-Conference for Engineering, Education, and Technology: "Engineering, Integration, and Alliances for a Sustainable Development" "Hemispheric Cooperation for Competitiveness and Prosperity on a Knowledge-Based Economy", 27-31 July 2020, Virtual Edition. 
An exemplary case of the problem in wastewater management is the city of Guayaquil case, belonging to the province of Guayas - Ecuador, approximately 280,000 $\mathrm{m} 3$ / day $(3.24 \mathrm{~m} 3 / \mathrm{s})$ of wastewater is generated during the dry season and $350,000 \mathrm{~m} 3 /$ day $(4.05 \mathrm{~m} 3 / \mathrm{s})$ in the rainy season; transported by sewer pipes [8].

There is a considerable amount of groundwater infiltration here, because sanitary sewers have a high level of deficiencies, along with the fact that most of the wastewater from these sewers, receives only primary treatments before being discharged to other bodies of water [8].

\section{Guayaquil's Wastewater Treatment Mechanism}

The mechanism used for the treatment and final disposal of wastewater in the city of Guayaquil, begins with the corresponding pipes of the sewage system which, its end are the wastewater collection centers, better known as pumping stations, these are distributed by sector or parish throughout the city of Guayaquil such as El Progreso, Pradera and Guasmo H [8].

The mechanism of these bases consists of a pumping system before being disposed off to the Guayas River, bringing as its main problems of degradation of the oxygen dissolved in the water, as well as bacteriological and aesthetic problems [8].

On the other hand, there are urban sectors that lack of a good sewerage system. These sectors are forced to install small wastewater treatment plants, consequently, are private. Among these sectors are urbanizations such as La Joya, Villa Club, Ciudad Celeste that have this type of treatment, where once the biological process is finished, the treated water is reused for irrigation of green areas [11].

But there are urban sectors and population groups that do not have the sewage pumping stations that exist in the city of Guayaquil and are also unable to install private treatment plants that, usually are very uneconomical [9], [14]. A clear example of this is what happens inside of the Orquídeas citadel, where its wastewater does not reach a complete treatment level and is stored some sort of lagoons, pools or deposits where they remain stabilized. In this case, these stabilization gaps are close to the human population and biodiversity causing different environmental impacts such as contamination of different classifications, nuisances, diseases, etc. [9], [14].

In addition to the fact of being a stabilization lagoon, that it does not meet the required standards that it must achieve, bringing other problems such as underground infiltration since they do not have any type of geomembrane as foundation in their structure. The transport pipes from the lagoon to the nearest pump station are obsolete, therefore generating underground infiltration and in some cases even spontaneous overflows [9], [14].

For this reason, the purpose of this research project was to promote, develop the use of biofilters based on natural filter beds for the purification of wastewater from the Orchid Stabilization Lagoon.

With this mission, it is considered through the development of two biofilters, one based on zeolite and the other based on activated charcoal, to find an effective method of purifying wastewater of natural origin, under the different regulations and standards stipulated by the Ecuadorian government, giving in turn a low cost investment, operation and maintenance. Always with the aim of improving the conditions and the quality of the water, thus providing a way to counteract the problems that arise in this lagoon, giving a useful value to its wastewater bodies, by reducing the different impacts that manifest itself.

\section{FILTER MEDIUM}

\section{ZEOLITE}

Zeolite is a crystalline hydrated aluminosilicate with three-dimensional structures, composed of aluminum, silicon, sodium, hydrogen and oxygen [3].

Characterized by its ability to retain and release water and exchange ions without modifying its atomic structure, it serves to exchange cations such as various compounds of phosphates, ammonia and components of organic matter [3]. It has a rigid three-dimensional structure (similar to a honeycomb) conformed by a network of interconnected tunnels that create a wide surface to perform cation exchange and moisture absorption. All zeolites are considered molecular sieves, which are materials that can selectively absorb molecules based on their size [3]. 
Zeolite allows water filtration in deep bed filters without the need to combine it with another filter medium, since it covers the specifications of giving depth to the filter bed and retaining particles up to 5 microns. Natural absorbent due to its high degree of hydration. High absorption capacity for gases and vapors. It has catalytic properties and ion exchange capacity [3].

Slightly reduces the acidity of the water, requires a lesser amount of product compared to others, due to porosity and density, has a larger surface area, produces greater clarity in the filtered water, is the most durable filter medium (more than 5 years), it only requires a simple periodic backwash to maintain its efficiency and performance, it has a flow capacity 4 times greater than that of conventional filter media, it has a higher retention capacity due to having a greater surface area [3].

\section{ACTIVATED CARBON}

Activated carbon are obtained from high carbon materials such as petroleum and vegetable or animal residues through chemical or physical treatments that increase their porosity so that they can adsorb many substances.

The starting materials for obtaining activated charcoal can also be algae, rice husk, sawdust, cottonseed husk, wood, fruit stones, these raw materials must have a high content of charcoal and minerals, and be easy to activate, high performance, low degradation during storage and low cost [5].

The name "Activated Charcoal" is applied to any form of charcoal characterized by its high adsorption capacity of gases, vapors, liquids and solids, which makes it particularly useful for many chemical, petrochemical and treatment processing industries. Activated charcoal as a filter medium is a material used to filter harmful chemicals and microorganisms from contaminated water [5].

In addition to retaining or filtering pesticides, fats, oils, detergents, disinfection by-products, toxins, colorproducing compounds, compounds from the decomposition of algae and plants or by the metabolism of animals [5].

As water flows through a granular activated charcoal filter, the compounds absorb or adhere to the surface, within the millions of micropores of the activated carbon granules. Activated carbon filters are always used as part of an extraction and treatment system to clean groundwater, river, lake, well, spring, etc. [5]

\section{BACKGROUND AND JUSTIFICATION}

Biofilters are a totally ecological purification mechanism for wastewater where different kinds of materials can be used, which we call filters, one of which is zeolite and activated charcoal, which work efficiently and economically, reaching notable purification levels, generating the removal of various agents from the same cleanse, such as oils, soapy water, dirt, microorganisms, etc. [4].

As identified on the trajectory of evaluations, analyzes and scientific projects, these minerals (zeolite and activated carbon), being a filter bed, contain a maximum purification of contaminants.

This is demonstrated by Villamarín, who, in his research proves that, by adequately adding natural zeolite in various granulometries and cationic modifications in the filtration systems, quite remarkable levels of water purification can be achieved and considerable removal of physical, chemical and biological parameters can be achieved such as: Total solids, with an initial concentration of $48,060 \mathrm{mg} / \mathrm{L}$, achieved a reduction of $2,375 \mathrm{mg} / \mathrm{L}, \mathrm{BOD}_{5}$ with an initial concentration of $22,780 \mathrm{mg} / \mathrm{L}$. and achieved a maximum reduction of $850 \mathrm{mg} / \mathrm{L}$, in COD an initial concentration of $78,865 \mathrm{mg}$ / $\mathrm{L}$, then a reduction of $2,241 \mathrm{mg} / \mathrm{L}$, Total Coliforms a concentration of $7,500 \mathrm{mg} / \mathrm{L}$, to a reduction of $324 \mathrm{mg} / \mathrm{L}$ and finally at $\mathrm{pH}$ a concentration of $(6.23 \mathrm{UpH})$, it is slightly acidic from the application, an increasing range of (6 to $9 \mathrm{UpH}$ ) was observed, through these concrete analyzes with an average general percentage of $95.06 \%$ efficiency [17].

Another study at the Technical University of Manabí - Ecuador, showed an analysis of residual water after applying scrubbing zeolite. Its methodology was based on the construction of a tubular system and inside of it, four layers of zeolite with different granulometry were conditioned, with the aim of promoting an adequate level of filtering and a short retention time in the system. Its most efficient results were in chemical parameters where it was possible to remove between $50 \%$ and $75 \%$ of the total nitrogen and especially the ammoniacal nitrogen from the samples taken, in phosphate a reduction percentage of between $50 \%$ and $95 \%$ was obtained, as

$\mathbf{1 8}^{\text {th }}$ LACCEI International Multi-Conference for Engineering, Education, and Technology: Virtual Edition "Engineering, Integration, and Alliances for a 
well as in $\mathrm{BOD}_{5}$, which presented improvements of up to $45 \%$ [15].

Consequently, in other parameters such as physics, the reduction was lower but with considerable percentages, the dissolved solids showed a reduction of $2 \%$ to $8 \%$, as well as the suspended solids, which decreased between $35 \%$ and $85 \%$. It was also possible to improve electrical conductivity up to $3 \%$ and dissolved oxygen can be improved from $2 \%$ to $7 \%$ [15].

In consideration of activated carbon, in the IberoAmerican Multidisciplinary Science and Engineering Symposium - 2013, scientists demonstrated that granular activated carbon (CAG) as a filter medium achieves considerable adsorption and purification capacities in contaminants. In their methodology they evaluated the methylene blue removal, first static tests were carried out per batch, the results of which were adjusted to the Langmuir model and allowed estimating a maximum adsorption capacity of $67.57 \mathrm{mg} \mathrm{AM} / \mathrm{g}$. [1].

To study the removal capacity of pollutants from an aquaculture effluent, five continuous tests were carried out on a packed column. In these tests, around $60 \%$ of the COD, UV254, N-NH4 + and P-total could be removed from the aquaculture effluent, while a decimal removal capacity of total Coliforms of 0.68 equivalent to $22 \%$, was observed on the outcome [1].

In the evaluation of the application of granular activated charcoal in the clarified water filtration of the Cauca River, the use of granular activated carbon in the filtration process to clarify the water was studied on a laboratory scale in order to analyze the removal efficiency of turbidity and matter, thus establishing the scope of the limit values recommended by international entities to reduce the microbiological risk in water for human consumption [7].

Through this investigation, it was found that, during 4 repetitions with the treatment, the proper selection of the operational conditions of the CAG filters can generate water that is comparatively similar or superior to the filters formed with conventional materials such as anthracite and sand. For example, in the final results of the Turbidity and organic matter parameters with CAG, turbidity removal efficiencies of up to $98.9 \%$ and records of up to 0.3 to 0.1 UNT were obtained in some cases; which would allow to possibly indirectly decrease the microbiological risk in the in water for human consumption [7]. $\mathrm{pH}$ values were also obtained in a range between 7 and 7.5 where it could favor a decrease in the number of $\mathrm{pH}$ modifiers used in the stabilization process [7].

\section{METHODOLOGY FOR IMPLEMENTATION OF BIOFILTERS.}

To determine which mineral-based biofilter is the most efficient for purifying wastewater from the Orquídeas Stabilization Lagoon, the collection, characterization, application and comparison methodology was proposed. It consisted of an exhaustive analysis of each one of the applied biofilters.

Mainly to identify the efficiency of the biofilters, simple samples were collected from the point of origin or place of study, which in this case is the Orquídeas Stabilization Lagoon. These simple samples were transformed into complex samples following the government processes and regulations stipulated by Ecuador [12], [13].

As explained hereunder, composite samples collected from the study site were analyzed to determine what condition it was in prior to insertion into biofilters, using physical, chemical, and biological parameters. This analysis is known as water characterization.

After establishing under what conditions was the wastewater stabilization lagoon Orquídeas. These waters were divided in half and applied in the corresponding biofilters, being one made of zeolite and the second one, activated carbon based to obtain a corresponding in each analysis.

The development of these biofilters was based on science and was exemplified by other which demonstrated the efficiency of wastewater treatment with the following minerals, zeolite and activated carbon. 
TABLE I

Composition of biofilters based on zeolite minerals and activated carbon

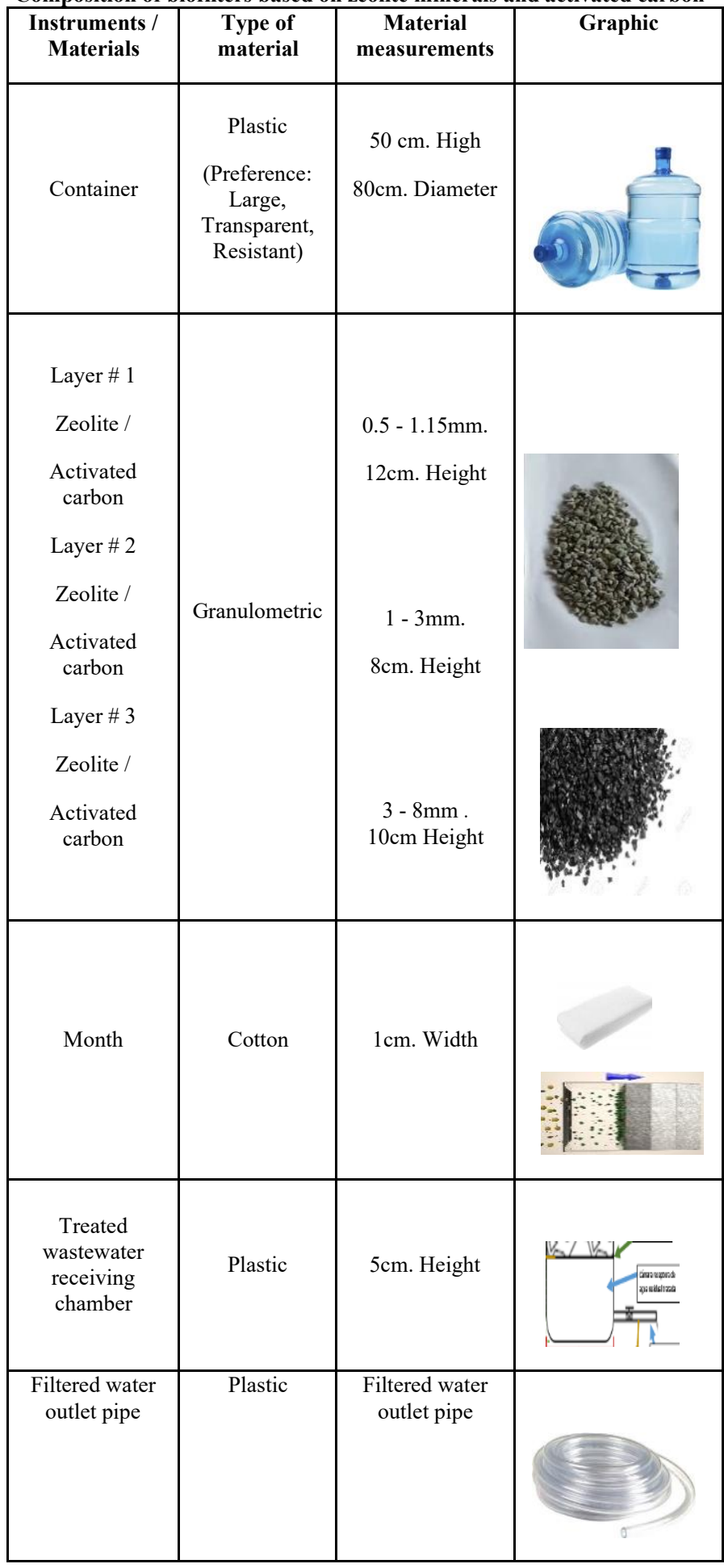

Source: Own authors year 2020.

TABLE I shows the structure, components and measures of the zeolite biofilter development and activated carbon biofilter that were used for the

purification of wastewater samples from the Orquídeas Stabilization Lagoon.

The structure and elaboration of these biofilters were identical so as not to distort the results of the samples belonging to each one.

It only had a corresponding change in the filter beds that were the zeolite and activated carbon minerals, which is the name use to identify each one. In biofilters, these filter beds are distributed as layers of different grain sizes (stone size).
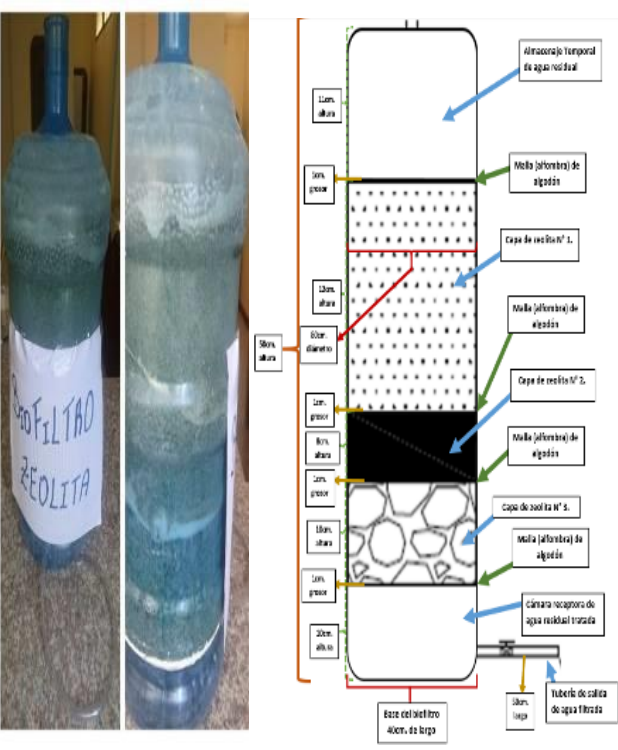

GRAPHIC I

Structural scheme of the biofilter based on zeolite and activated carbon Source: Own authors year 2020

As shown in GRAPHIC I, scheme used for the biofilter is similar, the only difference is in the filter material. These biofilters were created on a laboratory scale to demonstrate the efficiency of each one, in reducing the parameters stipulated by the project, the production of biofilters was with biodegradable and natural materials, materials that can be seen in the table above.

Following the residual water analysis procedure; It consisted of a water treatment with 4 repetitions for each biofilter. When the repetitions of each water treatment were completed with the corresponding biofilters, a resulting sample was taken; after the use of biofilters and having their samples resulting from each one. 
A comparison was made using statistical analysis to determine which one is the most efficient in the purification of wastewater.

\section{RESULTS AND DISCUSSION}

In TABLE II, the results indicate the matrix of alternatives developed by Wilcoxon statistical analysis, made during the execution of the proposed biofilters, considering that the results are demonstrated with the different physical, chemical and biological parameters that were stipulated in the project.

These results represent the percentage of reduction of pollutants. In turn, demonstrating differential value and $\mathrm{P}$ of the Wilcoxon statistical test, for greater. Checking the efficiency and difference of each o ne.

TABLE II

Comparison of the efficiency of treatments with Zeolite and Activated Carbon Biofilter using the Wilcoxon statistical method

\begin{tabular}{|c|c|c|c|c|c|}
\hline Parameter & \begin{tabular}{|c|} 
Characterization \\
Before
\end{tabular} & $\begin{array}{l}\text { Medium } \\
\text { Zeolite } \\
\text { Treatment } \\
\text { (Reduction } \\
\text { Value) } \\
\text { After } \\
\end{array}$ & $\begin{array}{l}\text { Medium } \\
\text { Activated } \\
\text { Carbon } \\
\text { Treatment } \\
\text { (Reduction } \\
\text { Value) } \\
\text { After } \\
\end{array}$ & Difference & $\begin{array}{c}\mathrm{P} \text { value } \\
\text { of the } \\
\text { Wilcoxon } \\
\text { test } \\
\text { (Null) }\end{array}$ \\
\hline $\begin{array}{l}\text { Turbidity } \\
\text { (Physical) }\end{array}$ & 770 NTU & $\begin{array}{c}97,50 \% \\
10.1 \mathrm{NTU}\end{array}$ & $\begin{array}{c}94 \% \\
15 \text { NTU } \\
\end{array}$ & $3,5 \%$ & 0,343 \\
\hline $\begin{array}{l}\text { Total Solids } \\
\text { (Chemical) }\end{array}$ & $5057 \mathrm{mg} / \mathrm{L}$ & $\begin{array}{c}94,5 \% \\
240 \mathrm{mg} / \mathrm{L}\end{array}$ & $\begin{array}{c}83 \% \\
560 \mathrm{mg} / \mathrm{L}\end{array}$ & $11,5 \%$ & 0,486 \\
\hline $\begin{array}{c}\mathrm{Ph} \\
\text { (Chemical) }\end{array}$ & $8.20 \mathrm{pH}$ & $\begin{array}{c}8,5 \% \\
7.10 \mathrm{pH}\end{array}$ & $\begin{array}{c}6 \% \\
7.96 \mathrm{pH} \\
\end{array}$ & $8 \%$ & 0,057 \\
\hline $\begin{array}{c}\text { BOD5 } \\
\text { (Chemical) }\end{array}$ & $295 \mathrm{mg} / \mathrm{L}$ & $\begin{array}{c}95 \% \\
17 \mathrm{mg} / \mathrm{L} \\
\end{array}$ & $\begin{array}{c}92 \% \\
70 \mathrm{mg} / \mathrm{L} \\
\end{array}$ & $3 \%$ & 0,057 \\
\hline $\begin{array}{c}\text { COD } \\
\text { (Chemical) }\end{array}$ & $591 \mathrm{mg} / \mathrm{L}$ & $\begin{array}{l}97 \% \\
10 \mathrm{mg} / \mathrm{L}\end{array}$ & $\begin{array}{c}94 \% \\
55 \mathrm{mg} / \mathrm{L}\end{array}$ & $3 \%$ & 0,057 \\
\hline \begin{tabular}{|c|}
$\begin{array}{c}\text { Fecal Coliforms } \\
\text { (Biologic) }\end{array}$ \\
\end{tabular} & $25 \mathrm{NMP}$ & $\begin{array}{l}58 \% \\
10 \mathrm{NMP} \\
\end{array}$ & $\begin{array}{l}44,50 \% \\
17 \mathrm{NMP}\end{array}$ & $13,5 \%$ & 0,886 \\
\hline
\end{tabular}

Source: Own authors year 2020.

As TABLE II points out, the results narrowly favor the zeolite biofilter, since its treatment shows that the different parameter have a greater reduction of contaminants.

The results display that the zeolite biofilter is above the activated carbon one, with differences in minimum and medium ranges. The most affected parameters were turbidity with $97.5 \%$, total solids with $94.5 \%, \mathrm{BOD}_{5}$ with total $95 \%$ and COD with $97 \%$

The parameters that reveals great difference between the two biofilters are: $\mathrm{pH}$ with $8.5 \%$ (Zeolite), $\mathrm{pH}$ with $\%$ (Carbon A.) and fecal coliforms with 58\% (Zeolite), fecal coliforms with $44.5 \%$ (Carbon A.).

To obtain more accuracy identifying the most efficient one, the biofilter treatments were subjected to a non-parametric statistical test called the Wilcoxon Method, which can be noted in TABLE II.

Differential values and $\mathrm{p}$, for each parameter demonstrating a null hypothesis in the test, that means and emphasizes the difference test results of each biofilter.

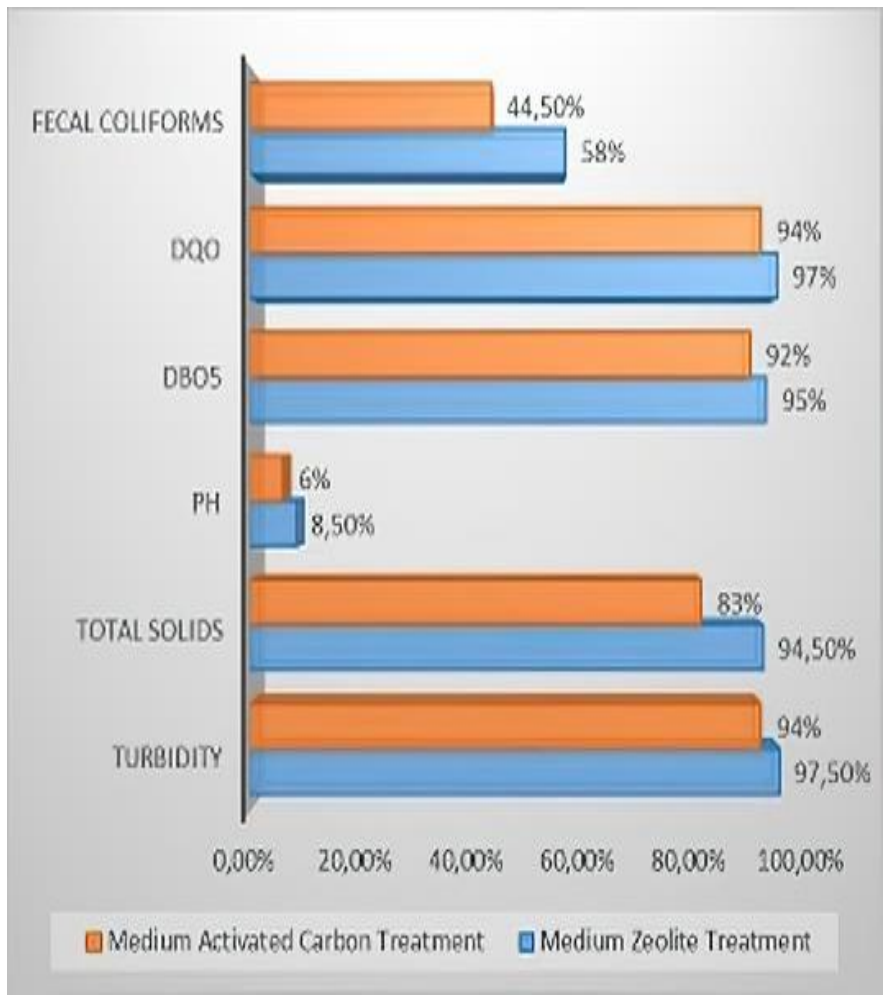

GRAPHIC II

Compared results in zeolite and activated carbon treatments using the Wilcoxon method

Source: Own authors year 2020

GRAPHIC II supports the information in TABLE II detailing and showing with greater detail the differences on the percentages between zeolite and activated carbon biofilters. 


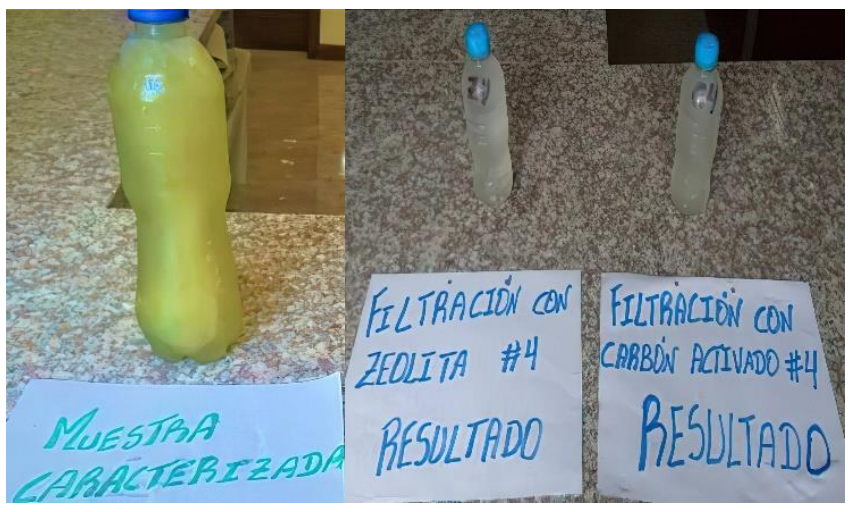

GRAPHIC III

Result compared to the four repetitions in biofiltration with the biofilter of zeolite and activated ed carbon

Source: Own authors year 2020.

GRAPHIC III details the difference visual between characterization and treatments results of biofilter zeolite and activated carbon biofilter, displaying a huge reduction on both.

The zeolite-based biofilter shows a greater reduction in pollutants from the wastewater of the Orchid Stabilization Lagoon. The clarity of the water observed in the sample denotes the effectiveness of the zeolite bio filter and its treatment, giving veracity to the results in the previous chart since the most affected parameters were turbidity, total solids, $\mathrm{BOD}_{5}$ and DQO.

\section{CONCLUSION}

The biofilters with minerals implementation project (zeolite - activated carbon) for residual waters purification in the Stabilization Lagoon of Orquídeas, Cerro Colorado - Guayaquil, obtained the verification of its purpose, giving as result, a solid solution to the existing problems:

On the wastewater characterization from the Orchid Stabilization Lagoon, an analysis was applied, following THE ECUADORIAN TECHNICAL STANDARD INEN 2176, 2013.

The results obtained from the parameters such as Turbidity, Total Solids, $\mathrm{BOD}_{5}, \quad \mathrm{COD}$ and Fecal Coliforms exceed the Maximum Permitted Limit, stipulated by the ENVIRONMENTAL QUALITY AND DISCHARGE STANDARD: WATER RESOURCE, (Regulation on the Control of Environmental Pollution in
Ecuador, 2015). The creation and implementation of zeolite and activated carbon based biofilters for wastewater purification were functional and successful, as there were several bibliographic references and previous works, in addition to the evidence results of each biofilter.

The most efficient biofilter for wastewater purification is the zeolite-based biofilter, as it allows a great reduction in most of the parameters studied, proving its efficiency.

\section{References}

[1] Aragón-Monter，R., \& Ramírez-Godínez，J. (2013). Use of Granular Activated Carbon (CAG) in a biofilter for the treatment of aquaculture effluents. Magazine of the Iberoamerican Multidisciplinary Science and Engineering Symposium. Polytechnic University of Pachuca, Mexico. Autonomous University of the State of Hidalgo, Mexico.

[2] Bermeo, D., \& Salazar, F. (2013). Optimization of the industrial wastewater treatment plant of a textile company

[3] Bish, D., \& Ming, D. (2011). Natural zeolites: witty, properties, applications. Virginia, USA: Virginia Polytechnic Institute \& State University Blacksburg, Virginia.

[4] Burgos, M., Brayan, E., \& Vinces, A. (2015). Analysis of the efficiency of zeolite-based filters for the removal of pollutants in the water from two public supply wells in the Tres Postes area, Alfredo Baquerizo Moreno Canton (degree thesis). ESPOL. Guayaquil, Ecuador.

[5] Colpas, F., Tarón, A., \& González, R. (2017). Surface area of activated and modified carbons obtained from the agricultural resource Saccharum officinarum. University cartagena. Cartagena Colombia. Journal of Agricultural Sciences , Volume 34 (2) - page 63,64.

[6] Economic Commission for Latin America and the Caribbean [ECLAC]. (2014). Diagnosis of water statistics in Ecuador. Approval of the final report of the Economic Commission for Latin America and the Caribbean, Constitution of Ecuador .

[7] Correa, A., \& Edwar, J. (2016). Evaluation of the application of granular activated carbon in the filtration of clarified water from the Cauca River (degree thesis). University of the Valley. Cali, Colombia.

[8] Municipal Company of Potable Water and Sewerage of Guayaquil" [EMAPAG]. (2017). General description of the universalization project of the sanitary sewer and wastewater treatment of the southern system of the city of Guayaquil "Las esclusas" wastewater treatment plant and its complementary components.

[9] González, A. (2017). Manufacture of sub-base for roads using residual sludge from wastewater treatment plants. Catolic university of santiago de guayaquil. Guayaquil, Ecuador .

[10] Jiménez, H., Acosta, L., Manrique, R., \& Herber, A. (2012). Regional project "Integrated wastewater treatment and use systems in Latin America". Obtained from IDRC - PAHO / HEP / CEPIS 2000 - 2002 Agreement . (General study of the San Agustín case). Lima Peru.

[11] Water planning in cities to live. (2016). 
[12] Londoño Carvajal, A., Giraldo Gómez, GI, \& Gutiérrez Gallego, Á. A. (March 2010). Analytical Methods for the Assessment of the Physicochemical Quality of Water (Reference Manual) (ISBN 978-958-8280-39-4 .) Obtained from Universidad Nacional de Colombia Sede Manizales - Faculty of Engineering and Architecture.

[13] Ecuadorian Technical Standard INEN 2176. (2013). NTE INEN 2176: Water. Water quality. Sampling. Sampling techniques .

[14] Sagubay. (2017). Evaluation of the stabilization lagoons of the orchids of the city of Guayaquil, University of Guayaquil. Guayaquil, Ecuador.

[15] Rodriguez Gamez, M., Guerrero Alcivar, M., \& Vázquez, A. (2018). Zeolite in decontamination of wastewater. Magazine of the Technical University of Manabi, Faculty of Mathematical, Physical and Chemical Sciences. Manabi, Ecuador, p. 1,2,3,6, 7.

[16] Technical Secretariat for Planning Ecuador [STPE], Technical Secretariat for Eradication and Poverty [SETEP], National Secretariat for Water [SENAGUA]. (2017). Drinking water and sewerage to eradicate poverty in Ecuador. Brochure of the Technical Secretariat Plan Ecuador, Technical Secretariat for Eradication and Poverty, National Secretariat of Water. Approved in July 2014 .
[17] Villamarín, D. (2017). Study of a biological filter for the control of effluents generated in a cheese factory in the Mulaló parish Latacunga canton, based on limestone, ceramic beads, zeolite and coconut shell granular activated carbon (degree thesis).

[18] LACCEI International Multi-Conference for Engineering, Education, and Technology : Virtual Edition "Engineering, Integration, and Alliances for a Sustainable Development" "Hemispheric Cooperation for Competitiveness in ess and Prosperity on a Knowledge-Based Economy", 27-31 July 20201 